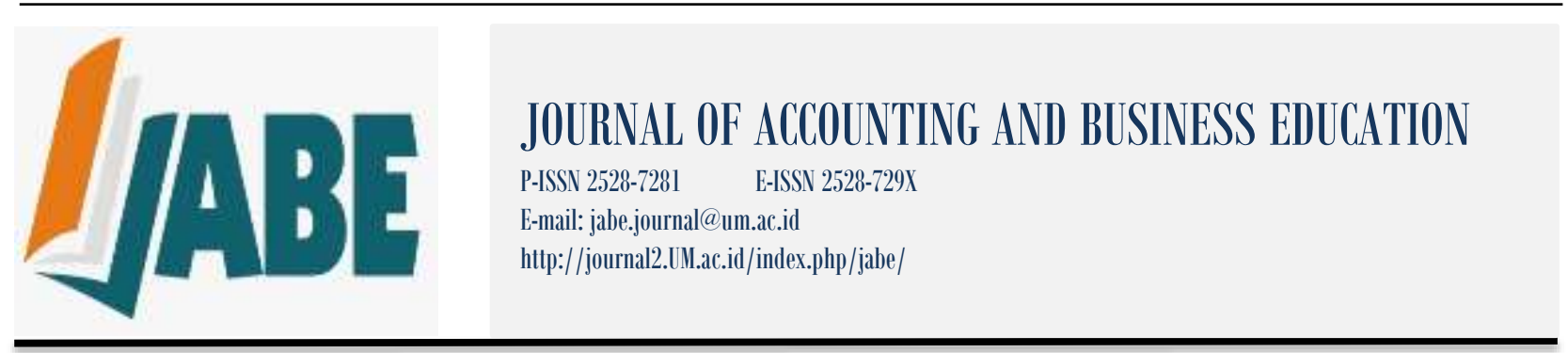

\title{
The Institutionalization of Remuneration (A Case Study at the University X)
}

\author{
Kharisma Yuanita Mahanani ${ }^{1}$ \\ Bambang Hariadi ${ }^{2}$ \\ Roekhudin $^{3}$ \\ ${ }^{1,2,3}$ Accounting Department, Faculty of Economic, Universitas Brawijaya, Indonesia \\ email: kharisma.mahanani@um.ac.id
}

DOI: http://dx.doi.org/10.26675/jabe.v4i2.7140

\begin{abstract}
This study aims to understand the process of institutionalization that occurred in the University X (UX) with their remuneration policy, starting from the idea of remuneration, remuneration discourse preparation, implementation and dissemination of remuneration. This is a qualitative research with case study approach to gain an understanding of the process of remuneration institutionalization at the UX. The results of this study indicate that the process of institutionalization of remuneration at the UX was related to external and internal factors of the organization. Determination of the remuneration regulation is the external pressure which must be accepted by the UX because it has implemented public service institution (BLU) financial management system. The idea of improving the quality of public services which was followed by the remuneration policy discourse and its application were not running well for the UX should face internal pressure from lecturers. In addition, education staffs who still do not have the application performance measurement weakens the process of institutionalization.
\end{abstract}

Keywords: Institutionalization, Remuneration, Public service institution

\section{INTRODUCTION}

Nonoptimal public service and increased number of corruptions lead to criticism directed towards the government performance. For this reason, the idea of tidying up the government system has been an important agenda for the government in order to manifest good governance. It is expected that the newlyemerging paradigm on New Publik Management (NPM) would replace the inefficient old public administration in public service, unknown performance, and even ignorance to what the people need. Adopting NPM helps the implementation of reform in public sector by targeting a change in institutional order, employment as well as financcial management (Hood, 1991). According to Mahmudi (2003), applying NPM not only change the rigid, bureaucratical and hierarchical traditional management of public sector into a more flexible and market-accomodating one, rather it also constitutes a form of public administration modernization, power depoliticization or authority decentralization which encourages democratization.

Public sector reform has been promoted by the central government as an attempt to tidy up its administrative system. Improved service to the community is one of important goals in this public sector reform. As the realization of this attempt of improving service given to the community, the government established public service instituion (BLU) or Public Service Agency which focused on services to the community. Under Law Number 1 Year 2004 on State Treasury Article 1 point 23, BLU is the instituion 
within the Government established to provide services to the community as embodied in its effort to supply goods and/or services sold without prioritizing profit gain and in doing its job the principles of efficiency and productivity should be the basic consideration".

University X (UX) is a college which applies BLU Financial Management or $B L U$ financial management since 2008 as established by the Decision Letter of Minister of Finance No. 279/KMK.05/2008 dated 24 September 2008. As one of the impacts of applying BLU financial management, UX can now provide its employees with remuneration based on the required responsibility and professionalism demand. This remuneration was proposed by the Rector and then established under the Decision of Minister of Finance. Remuneration is a reward given to managing officials, supervisory board and employees of BLU. Remuneration can be salary, incentive, honorarium, fixed allowance, bonus, severance pay or pension. The legal basis in preparing remuneration is Permendikbud number 77 year 2014. In reference to this regulation, the amount of remuneration shall be based on the number of students, non-tax state income (PNBP), asset size and performance target achievement.

Many previous studies on remuneration associated it with civil servant's performance. The managerial performance of financial management officials at state colleges increased when their leaders applied participatory numbering and remuneration and followed with the application of knowledge sharing in the organization (Kawedar, 2015). In line with this research, the study conducted by Gustika (2013) found that providing remuneration significantly influenced civil servant's performance. However, a different result was obtained by Rusman (2015) who studied the influence of remuneration, organizational culture, demographic characteristics and functional monitoring on the performance of financial managament employees at Religious Affairs Ministry Office of Southeast Sulawesi Province. He found that the distribution of remuneration which was not based on performance assessment and workload made the employees thought they had been treated unfairly, resulting in the failure to achieve the expected performance improvement. According to Rusli (2013) a remuneration system should integrate performance, employee's competence and dedication while still complying with the reward and punishment principle. Remuneration policy needs to be refined in terms of its regulation, factorial evaluation system, and revision of score assignment model and office class (Alawiya et.al, 2013). The remuneration systems for lecturers and management should be diversified and updated continuously to reflect the occuring intellectual development (Blaskova and Blasko, 2014).

UX has provided remuneration to all of its employees since 1 January 2015 . This is what attracts the researcher to study the process of how remuneration is implemented by analyzing it from organizational point of view. The process of institutionalizing remuneration at UX can be studied using New Institutional Sociology (NIS) framework. Hariadi (2013) suggests that institutionalization is a process that an organization does to make itself remains acceptable to its institutional environment by imitating or emulating other organizations (isomorphic). DiMaggio and Powell (1983) explains three ways how an organization imitates or emulates (isomorphic) its institutional environment, i.e. coercive, mimetic and normative ways. The establishment of regulation on BLU financial management forces UX to implement the remuneration institutionalization processes. This is a form of coercive isomorphism in which the organization receives pressure from the state to make some change by providing remuneration for its employees. According to Jones (2001), organization change is a process made by the organization from the existing condition to a new one which is expected to match the organization's goals in improving their effectiveness. This goes hand in hand with the goal of implementing remuneration within BLU, i.e. to have an effective and efficient public service. Remuneration policy is expected to improve employee's performance and, in turn make the public service more effective and efficient.

The research conducted by Hariadi (2013) explains the dynamic of institutionalization process in PG Krebet Baru with revitalization strategy. His research result shows that the institutionalization process of sugar plant revitalization is influenced by accounting role. The HPP calculation determined by the government shows how accounting plays a role as the government's political tool in maintaining inflation. Nurdiwaty (2014) conducts a study on the institutionalization of social accounting at the Blitar StateOwned Forestry Enterprise. In her study, Nurdiwaty shows that the regulation which requires Blitar StateOwned Forestry Enterprise to perform social accounting in the form of partnership and environmental 
guidance program (PKBL) and the encouragement from the management serve as the institutionalization processes and these are classified as coercive and normative ones.

Previous studies on remuneration focus more on theoretical review of regulations of law established by the government. Additionally, some remuneration-related studies use quantitative approach by performing statistical test. What makes this research different from those previous studies is that it uses qualitative approach. This is intended to understand the institutionalization process of remuneration at UX. Also, this research uses NIS framework by adopting the Institutionalization Process Model (IPM) developed by Dambrin et al. (2007) which, to the best of the researcher's knowledge, has never been done in studying remuneration previously.

\section{LITERATURE REVIEW}

Institutionalism constitutes a school of thought in organizational study which has its root on sociology. According to DiMaggio \& Powell (1991), institutionalism developed as a response to behavioral study domination. An institutionalism expert sees that an institution or organization interacts through institutionalization process and they also believe that the way an organization institutionalizes new practices is contextual and culturally embedded. This is different from a behaviorism expert who sees an organization as a group of individual characteristics.

One of the theoretical frameworks which have been used to evaluate public sector reform is New Institutional Sociology (NIS). As found by Covaleski et al. (1993) and Dambrin et al. (2007), NIS provides a valuable perspective in informing organizational process and accounting change. This has something to do with public sector where the needs of public sector organization are budgeted to achieve the legitimacy with the public fund provider.

In NIS perspective, the attempt made by an organization to institutionalize certain practices is not just encouraged by the motivation of finding efficiency, rather this effort is also driven by the motivation to obtain organizational acknowledgment or legitimacy. Organization legitimacy is obtained through isomorphism, i.e. the behavior practiced by an organization by uniforming certain practices in order to emulate its institutional environment (DiMaggio \& Powell, 1991). Isomorphism is a method and character of institutionalization which can be either coercive, mimetic or normative. Coercive isomorphism occurs when an organization is dictated by another power to change its regulations in the form of procedure, structure, management style or other habits. The power can be legal regulations or threats from the authority to put a halt on the vital resources needed by the organization.

Changes come not only from external power, rather reproducing another organization's success in managing innovation is another form of change made by the organization known as mimetic isomorphism. Normative isomorphism is driven by the organization's internal party who believes that the organization's superiority can only be achieved by institutionalizing new rules, procedures or practices which require employees to attend training and the organization to hire professional consultants.

This research investigates how and why the actor comes for institutionalizing a remuneration system. Institutionalization is used as an extensive theoretical framework in this research by using Institutionalization Process Model (IPM) suggested by Dambrin et al. (2007) to see the processes through which the remuneration institutionalization occurs. Taken from the model previously developed by Harun et al. (2012) and Dambrin et al. (2007), it offers a certain value framework in this research since it has something to do with processes; particularly with how the initial idea pops up, is developed, prepared and implemented as a social construction. According to Dambrin et al. (2007) to obtain the complete picture (of institutionalization), four stages need to investigated consist of Propagation of new idelas (New Ideals); Description of new ideals in developing policies (New Discourses); Development of certain management tools based on new ideals (New Technique); and Implementation of predetermined techniques (Internalization).

The first stage, i.e. propagation of new ideals, normally occurs beyond the organization, and the next stage is usually also triggered by internal factors (Dillard et al. 2004). This is possible in public sector since a certain external authority has an influence in forming remuneration policies. According to Dambrin et al. 
(2007), the institutionalization process is incomplete when no "Discourses" nor "Technique" are involved and "Internalization" has taken place. For an institutionalization process to be "successful", there should be correlation between New Ideals, New Discourses, and New Techniques. This means the implementation of a system is only possible when the actors see that the system practice needs to be done and committed to do so (Dambrin et al., 2007, p: 176).

When an institutionalization process fails, then the goals to be achieved by the policy will also be gone. According to Dambrin et al. (2007, p. 176) in the absence of internalization, loose coupling or decoupling will occur and the practice of that policy is merely ceremonial. Thus, the success of an institutionalization process depends on the internalization of new policies needed in line with the initial ideals (such us using remuneration to improve performance in public sector) as reflected in the actions of those applying it. Hence, there is a correlation between new ideals, new discourse, new technique and and internalization (Dambrin et al., 2007, hal: 178).

In other words, the process of remuneration institutionalization may be officially implemented, yet the other problem is that whether or not it can also be used to measure performance and HR management in line with the initial purpose of this policy. Remuneration in accordance with PMK No. 10 Year 2006 is defined as a reward which can be salary, honorarium, fixed allowance, incentive, bonus for achievement, and/or pension. Remuneration is the payment made to employees by an organization as a reward for their contribution to the organization (Rusli, 2013).

It is expected that the provided remuneration meets the feasibility and justice elements, thus its implementation needs to consider the pay for 3 P's principle (Regulation of Minister of Health No 68 Year 2014), namely:

1. Pay for position which is a type of remuneration directly related to the job and serves as a reward to employees for their willingness and commitment in performing the job demand. This kind of remuneration has something to do with the position assumed by employees, thus the higher one's position, the greater the remuneration value received by the employees. The amount of this remuneration is fixed and paid on monthly basis.

2. Pay for performance which is a type of remuneration related to the achievement of total performance of the contracted work and serves as a reward to employees for their individual total performance achievement so that the employees with good performance deserve high remuneration. This remuneration can be incentive or bonus and paid periodically as per the work unit policy.

3. Pay for people is a remuneration policy related to the individual condition which is worth awarding for their expertise and competence and thus the more skilled an employee, the greater amount of remuneration they will receive. The amount of this remuneration is varied, depending on their performance and usually paid on monthly basis.

In giving remuneration, some factors ought to be carefully considered, namely proportionality, equity, appropriateness and operating performance of BLU (PMK No. 10 Year 2006 jo. PMK No. 73 Year 2007). Proportionality is the consideration given to the size and number of assets managed by BLU and the level of service, thus the greater the assets of a BLU work unit, the higher their ability in providing remuneration. Equity means the consideration made to the similar service industry to prevent any excessive gap in providing this remuneration. Appropriateness means the adjustment made to BLU's ability to provide remuneration so that it will not be too much for the work unit's finance. Operating performance of BLU is set by the Minister/Institution Leaders by taking financial indicators into account, services, quality and benefits for the society. Generally, remuneration policy is related to employee's welfare. Providing adequate remuneration can result in improved productivity and performance achievement. Providing remuneration is expected to motivate workers to achieve the organization's goals and creates a harmonious work atmosphere. 


\section{METHODS}

Qualitative research has been widely used in social sciences such as psychology, anthropology, sociology and law. As time flies, accounting and management begin to use this type of research. This is influenced by the issue of Burrell and Morgan's book in 1979 on sociological analysis of organization. Qualittative research is selected as this research approach. Qualitative research is a process of study to explore and understand the meaning of social or human problems by collecting and analyzing data and, eventually, presenting the report scientifically which include the voices of the participants, reflectivity of the research and its contribution to changes (Creswell, 2015:59). Qualitative research has its own strength in its greater flexibility since it can be adjusted to the existing conditions and the process of data collection can be adjusted with how the research is developing (Denzin and Lincoln, 1998 in Basuki, 2006:84). According to Sukoharsono (2006), conducting qualitative research requires a strong commitment, sufficient time, and reliable resources.

Integrating it with the institutionalization phenomenon, i.e. the process where new ideas or practices are adopted by an organization to be a habit, then the use of qualitative in this research is justified since it matches the characteristic of qualitative research. Processual research can be conducted more easily in a more cautious way using qualitative method since its wider targets and detailed questions can be accomplished using this method.

The strategy used in this research is case study to provide in-depth analysis on institutionalization practice. Yin (2002) suggests that a case study is useful when the research aims to to answer "why" and "how" questions. A case study is a form of inquiry or study on a problem of particular nature (particularity) and it can be conducted using either qualitative or quantitative approach, targeting individual and group, and even the public in general (Salim, 2001). Kamayanti (2016:98) states that a case study can be used as an approach to understand the dynamic occuring under certain circumstances.

This research is done at University X. This location is selected based on several considerations, i.e. firstly University X has been a Public Service Agency work unit with a full BLU status under the Decision Letter of Minister of Finance No. 279/KMK.05/2008 dated 24 September 2008. As a BLU work unit, University $\mathrm{X}$ has also been appointed as BLU work unit with remuneration system for its employees in accordance with the Decision of Minister of Finance of The Republic of Indonesia Number 390/KMK.05 Year 2015. Since the establishment of that regulation, University X has implemented BLU remuneration for 2 years. The second consideration is the availability of access to conduct research at University X. In qualitative research, the availability of access to a location is highly important. Qualitative research with case study approach needs a more familiar and natural relationship and growing trust, thus accessibility is ultimately needed. Finally, the third consideration includes costs, time and energy.

The data used in this research come from interview notes and documents related to this research. The informants involved in this study play different roles and have different interests in the organization which include policymakers, technical guidance drafters and performance assessors. This research is conducted by interviewing some informants, including:

Table 1. Informant Information

\begin{tabular}{lll}
\hline \multicolumn{1}{c}{ Institutionalization Stages } & \multicolumn{1}{c}{ Informants } & \multicolumn{1}{c}{ Keywords } \\
\hline New Ideals & $\begin{array}{l}\text { Head of Subdirectorate of BLU Financial } \\
\text { Coaching for Education (Ministry of Finance) }\end{array}$ & National-wide Remuneration \\
New Discourses & $\begin{array}{l}\text { Head of PNBP Sub-division (Ministry of } \\
\text { Research, Technology \& Higher Education) }\end{array}$ & $\begin{array}{l}\text { Remuneration at ministry/ institution } \\
\text { level }\end{array}$ \\
& Deputy Rector II (University X) & UX remuneration policy \\
New Technique & Expert staff of WR II (University X) & $\begin{array}{l}\text { Remuneration technical guideline } \\
\text { Head of employment division (University X) }\end{array}$ \\
& $\begin{array}{l}\text { Mechanism for assessing educator's } \\
\text { performance }\end{array}$ \\
\hline
\end{tabular}




\begin{tabular}{lll}
\hline & Head of financial division (University X) & Remuneration payment mechanism \\
Internalization & $\begin{array}{l}\text { Deputy Dean II (Faculty of Education, FIP } \\
\text { University X) }\end{array}$ & Performance evaluation \\
& $\begin{array}{l}\text { Deputy Dean (Faculty of Psichology, FPPsi Performance evaluation } \\
\text { University X) }\end{array}$ \\
\hline
\end{tabular}

The researcher also collects data through observation, i.e. directly observing and taking notes on the symptoms or phenomenon studied within University X. This observation is done while making field visit, including when collecting evidences, such as interview. In this observation, the researcher is also participating since the researcher is also involved in the activity of those to be studied who serve as sources of research data. In this research, the researcher serves as staff of BLU finance division at University X.

When collecting data, the researcher focuses this researcher on the institutionalization stages using IPM model developed by Dambrin (2007). This model matches the formulation (of objective) in this research, i.e. to understand how the occuring process of remuneration institutionalization was. As to the focuses of investigation in this research, they are detailed in the following table:

Table 2. Investigation Focuses

\begin{tabular}{ll}
\hline \multicolumn{1}{c}{ Institutionalization Stages } & \multicolumn{1}{c}{ Investigation focus } \\
\hline New Ideals & Initial ideas for remuneration \\
New Discourses & Discourse for developing and establishing remuneration system at the University X \\
New Techniques & Formulation of remuneration system at the University X \\
Internalization & Implementation of remuneration \\
\hline
\end{tabular}

\section{RESULTS AND DISCUSSION}

\section{New Ideals}

Remuneration is an integral part of BLU financial management mechanism. University X (UX) as a state institution assigned with BLU status should completely accept the consequence as set forth in GR No. 23 Year 2005, including regarding the implementation of remuneration. This is as stated by Head of Subdirectorate of BLU Financial Coaching for Education (Ministry of Finance) below:

"We also have to see this remuneration as an integral part of BLU financial management mechanism. This is because GR 23 is the first (rule) to govern (this matter). Thus, (deriving) from Treasury Law, the technical regulation below it is GR 23. It is from this GR 23 that the remuneration mandate begins. When a state institution is assigned with BLU status, such as UX, then UX should completely accept the consequence in GR 23 to which they should ultimately, rather than half-heartedly, comply with."

Since the issueance of GR No. 23 Year 2005 on financial management for public service agency (BLU), it took fairly long for UX to apply remuneration. This could not be separated from the resulting polemic, starting with the use of word "dapat" (may) in article 36 of GR No. 23 Year 2005. With this "dapat" word, does it mean BLU should impelement remuneration or do they have another scheme to implement. Additionally, at nearly the same time, all state institutions perform the performance allowance. This is as suggested by the Head of Subdirectorate of BLU Financial Coaching for Education (Ministry of Finance) below:

"What makes it too long between BLU establishment and remuneration implementation is more likely due to technical issues regarding infrastructure preparation, technical guidance to translate article 36 of GR 23. The mandate has been there, yet almost all new BLUs implement remuneration in 2014. There was 6-year time lag, and for these 6 years many considerations 
should be carefully discussed, including when the provision of performance allowance was implemented."

Initially, state universities and colleges under the Ministry of Education and Culture received performance allowance in 2013 under the Presidential Regulation No. 88 Year 2013 since at that time not many state universities and colleges had implemented remuneration. Since the reign shifted to President Joko Widodo, from 2015 state universities and colleges were under the responsibility of Ministry of Research, Technology and Higher Education. The provisions on performance allowance in Ministry Research, Technology and Higher Education were set forth in Presidential Regulation Number 32 Year 2016. In its practice, some BLU state universities and colleges had not implemented remuneration. This is as stated by the Head of Sub-division PNBP (Ministry of Research, Technology \& Higher Education) below:

"From 29 BLU state universities and colleges under the Ministry of Research, Technology \& Higher Education, 19 have obtained KMK on remuneration. Institutional Ministry (KL) only gave warning for those state universities and colleges which had not submitted remuneration. No certain sanction, even to those BLU state universities and colleges which had no KMK yet, we still gave them tukin"

The establishment of regulation on remuneration is a form of external pressure that UX must receive. Regulation as external pressure has been the most common form of coercive isomorphism (Harcourt et al., 2005). This pressure is not there randomly; there is an ideal that the government wanted to achieve in realizing better public service, particularly in terms of HR, behind this pressure. Remuneration is tightly related to the issue of human resource management (SDM). HR management had 3 components, namely: human resources, performance assessment and reward. Remuneration cannot be separated from the final goal of BLU, i.e. better public services. This opinion is uttered by the Head of Subdirectorate of BLU Financial Coaching for Education (Ministry of Finance) below:

"It is highly important to implement remuneration and the room in need of improvement is its HR. This is because it will be "non sense" if the attempt is made, yet the persons to give the services are not prepared well. If I give you more incentive, you will work better, and that is exactly the assumption."

The initial idea for remuneration came from beyond the organization, in this case the government by establishing regulations on remuneration. The first institutionalization stage, i.e. propagation of new ideals, normally came from the outside of the organization (Dillard et al., 2004). This is possible since external authority (central government) holds an influence in determining the remuneration policy. The first stage in institutionalization, i.e. propagation of ideals (new ideals) can be said as successful if it is followed by developing policies, new techniques and internalization (Dambrin et al., 2007).

\section{New Discourses}

UX holds the autonomy in managing their financial resources more flexibly, without violating such principles as efficiency, transparency, and accountability. One of the outcomes of this status is that in 2014 under the Decision of BAN PT number 250/SK/BAN-PT/Akred/PT/VII/2014, UX are instititionally accredited A. In the future, in order to improve its institutional capacity and capability and strengthen its independence, UX prepare themselves towards the State University and College as a Legal Entity (PTN BLU) status in accordance with Law Number 12 Year 2012 on Higher Education. This is stated by Deputy Rector II below:

"What is clear is that UX planned to be PTN BLU, earlier it even went as far as nearly becoming PTN BH, yet since the Law was revoked, we were then directed to PTN BLU, rather than directly becoming PTN BH. I remembered, we had reviewed various PTN BH around 2005/2006. Yet, at the end of the day UX changed its direction to be PTN BLU first and in 2008 we officially became PTN BLU" 
Remuneration is one of the privillege owned by UX as BLU work unit. Remuneration is one of the consequences that UX should implement since it uses BLU financial management mechanism. Deputy Rector II also stated his opinion below:

"Remuneration, I recalled, on 6 April 2015 through the Decree of Minister of Finance for UX. Had it not been established, we would not give the remuneration. Thus, we had the basis. If one said it was forced, it could be so. Yet, it was also due to (our own) awareness after the Decree of Minister of Finance was issued."

Remuneration is a reward which can be salary, fixed allowance, honorarium, incentive, bonus for achievement, severance pay, and/or pension. To determine remuneration, such principles should be considered: proportionality, equity, appropriateness, and operating performance. In addition, in giving remuneration, the extent of responsibility and professionalism demand should be the main considerations. Remuneration was implemented after it was established under the Decision of Minister of Finance upon being proposed by the Minsiter of Education and Culture/UX leaders. The payment of remuneration should reflect fairness (equal pay for jobs of equal value) and consider the financial ability (PNBP). This is as suggested by Deputy Rector II below:

"If we still unable to do it, we should prepare the structure. Only then it can be realized under the Decree of Minister of Finance. The main requirement to submit proposal to be BLU is being capable in terms of finance, particularly since this remuneration came from PNBP, rather than from RM. Thus, if PNBP can, then go ahead and PNBP for remuneration is, at its maximum, $40 \%$. Then, it terms of the amount being paid, it depends on our own ability."

Based on the Minister of Finance Act Number 10 Year 2006 article 3, the amount of remuneration for BLU leaders is determined by considering several factors, namely: (1) proportionality, i.e. consideration of size and amount of assets managed by BLU and quality level. UX as BLU Work Unit manage assets of over Rp 2 billion worth. (2) Equity, according to Deputy Rector II, UX applies benchmarking to measure the equity factor with considerations as follows:

"For consideration, well we referred to UC since this university at that time was the only public university or state university or college which had implemented remuneration. In addition, UX also referred to UA for the basis of equity. Judging from the Number of Services, both the Number of Students, Study Programs, and Faculties, (we are) on par with UA"

The benchmarking process is a form of mimetic isomorphism, i.e. imitating the success of another university in managing innovation (Dimaggio \& Powell, 1983). The result of benchmarking performed by $\mathrm{UX}$ in detail can be seen in the following table:

Table 3. Benchmarking Result Table

\begin{tabular}{lcccc}
\hline \multicolumn{1}{c}{ Description } & UX & UA & IB & UC \\
\hline Income of PNBP 2013 & Rp 253 Billion & Rp 139 Billion & Rp. 268 Billion & Rp. 124 Billion \\
Asset Value & Rp 923 Billion & Rp 1,2 Trillion & Rp. 2,2 Trillion & Rp. 1,5 Trillion \\
Number of Faculties/PPS & 9 Faculties & 9 Faculties & 5 Faculties & 12 Faculties \\
Number of Study Programs & 92 Study programs & 97 Study programs & 63 Study programs & 50 Study programs \\
Number of HR (personnel) & 1990 & 1,643 & 1,747 & 1,790 \\
Number of Students & 29,106 Students & 33,813 Students & 17,485 Students & 22,750 Students \\
Performance Assessment & 79.35 A-GOOD & 72.04 A-GOOD & 75.78 A-GOOD & 80.51 AA-GOOD \\
Rector Remuneration & Rp 21.4 Million & Rp 21.9 Million & Rp.20.4 million & Rp.22 million \\
& (PNBP) & (PNBP) & (PNBP) & (PNBP) \\
\hline
\end{tabular}

Source: UX Internal Data 
(3) Appropriateness, i.e. adjusting the relevant BLU's financial ability.

Table 4. Income Trend, Assets and Equity of UX

\begin{tabular}{clccc}
\hline $\mathbf{N o}$ & & $\mathbf{2 0 1 1}$ & $\mathbf{2 0 1 2}$ & $\mathbf{2 0 1 3}$ \\
\hline $\mathbf{1}$ & Income & $153,559,208,340$ & $160,395,821,197$ & $254,397,011,049$ \\
$\mathbf{2}$ & APBN Funding & $223,575,478,431$ & $198,854,854,400$ & $242,887,364,246$ \\
$\mathbf{3}$ & Assets & $902,785,506,562$ & $961,702,418,003$ & $923,636,751,181$ \\
$\mathbf{4}$ & Equity & $902,785,506,562$ & $957,288,176,189$ & $855,724,993,820$ \\
\hline
\end{tabular}

Source: Financial Statements of BLU UX 2011-2013

(4) Operating performance of BLU, i.e presenting the operating performance set by minister/institution leader which at least considers such indicators as finance, services, quality, and benefits for the society.

Table 5. UX Performance Assessment Results

\begin{tabular}{ccccccc}
\hline No & Year & $\begin{array}{c}\text { Finance } \\
\text { Score }\end{array}$ & $\begin{array}{c}\text { Services } \\
\text { Score }\end{array}$ & $\begin{array}{c}\text { Total } \\
\text { Score }\end{array}$ & Category & Note \\
\hline 1. & 2011 & & & 75.32 & A-GOOD & No.: KEP-01/PB.5/2012, 20 Nopember 2012 \\
2. & 2012 & 24.45 & 54.91 & 79.35 & A-GOOD & No.: KEP-219/PB.5/2013, 31 Desember 2013 \\
\hline
\end{tabular}

Based on the financial analysis made, UX has calculated the amount it needs to pay its remuneration at Rp 101,449,525,354.00 which comes from PNBP fund. This amount of fund to fulfill the needs to fund remuneration for 1,990 personnel consisting of educators and education staff who are both civil servants and non-civil servants under the Rector's Decision Letter.

The proposal of remuneration is sent to the Institutional Ministry (KL) in this case the Ministry of Research, Technology \& Higher Education for verification. This verification performed by KL is a hierarchical control mechanism, as suggested by the Head of PNBP Sub-division (Ministry of Research, Technology \& Higher Education) below:

"BLU is a line up or an extension of KL. KL operator in providing services. Since university is a line up of KL, there is a hierarchical consequence here. It should be noted that every activity made by BLU, it has an impact on KL. This is because BLU spending will be a part of KL spending. If we talk about remuneration, we also talk about spending sector of employees. BLU's income becomes KL's income. This shows a hierarchical control mechanism from BLU up to KL"

The process of reviewing remuneration proposal made by Ministry of Finance is not too different from the verification by KL, i.e. taking into account 4 aspects in remuneration proposal. This is as stated by the Head of Subdirectorate of BLU Financial Coaching for Education (Ministry of Finance) below:

"we as assessor team will see the appropriateness between one rector and the other. For a rector, wherever they are, their main tasks and functions are the same, including their work load, they are the same. The difference is maybe in terms of the volume. Thus, equity is still considered. Therefore, it is still necessary to compare with similar industry."

After passing some stages in the remuneration proposal process, on 6 April 2015 UX was appointed BLU work unit with a remuneration system for its employees as per the Decision of Minister of Finance The Republic of Indonesia Number 390/KMK.05 Year 2015. KMK is the result of breaking down ideals (new ideals) into policy development (new discourses). This policy development is related to the 
remuneration institutionalization process and it is reflected by the actions taken by the people implementing it (Dambrin et al., 2005).

\section{New Techniques}

Each of those BLUs implementing remuneration has special the Decree of Minister of Finance on remuneration system which is applicable in the said work unit as explained by the Head of Subdirectorate of BLU Financial Coaching for Education (Ministry of Finance) below:

"Specifically, BLU has a Decision of Minister of Finance on remuneration, each BLU must have it (the Decree of Minister of Finance). The detail on how to pay it, the BLU leaders must make the technical guidelines based on it."

From what is suggested by the Head of Subdirectorate of BLU Financial Coaching for Education (Ministry of Finance), the next step that UM must take after the establishment of the Decree of Minister of Finance is to prepare technical guidelines and established as Regulation of Rector. As per the Decree of Minister of Finance No. 390/KMK.05 Year 2015, UM gives remuneration to BLU leaders, Finance Officials and Technical Officials, Head of Supervisory Board, Secretary of Supervisory Board, and members of Supervisory Board, as well as UX employees.

\section{Table 6. UX Remuneration Object}

\begin{tabular}{|c|c|c|c|}
\hline No & Remuneration Object & Work Unit & Name of Management Officials \\
\hline 1 & The Head & University & Rector \\
\hline 2 & Chief of Financial Affairs & University & $\begin{array}{l}\text { a. Deputy Rector II } \\
\text { b. Head of General \& Financial }\end{array}$ \\
\hline \multirow[t]{3}{*}{3} & Operational Chiefs & University & $\begin{array}{l}\text { a. Deputy Rectors I, III, and IV } \\
\text { b. Head and Secretary of Institution } \\
\text { c. Head of AKPIK Bureau } \\
\text { d. Head of UPT/Laboratorium/Office/Study } \\
\text { Center/Service Center }\end{array}$ \\
\hline & & Faculties/ Postgraduate & $\begin{array}{l}\text { a. Dean/Director of Ppstgraduate } \\
\text { b. Deputy Dean/Postgraduate } \\
\text { Director Assistant }\end{array}$ \\
\hline & & Department/Study Program & $\begin{array}{l}\text { a. Head of Department/Study } \\
\text { Program/Division }\end{array}$ \\
\hline 4 & Supervisory Board & University & $\begin{array}{l}\text { a. Chairperson } \\
\text { b. Secretary } \\
\text { c. Members }\end{array}$ \\
\hline 5 & $\begin{array}{l}\text { BLU Employees } \\
\text { (Educators and Education } \\
\text { Staff) }\end{array}$ & $\begin{array}{l}\text { University/Faculties/ } \\
\text { Postgraduate }\end{array}$ & \\
\hline
\end{tabular}

UX's remuneration applies Pay for Position concept at a value given on monthly basis and Pay for Performance to determine the remuneration amount to be received by employees. In BLU financial management mechanism, there is a public service agencification. The government as the goods and services providers is not directly in touch with the society, rather it forms an agency to give the public service and this role is played by BLU. The government as the principal and the agent as the service provider agree on a performance contract. In this performance contract, it set forth that the performance that BLU must achieve. This performance achievement is then assessed and used as the basis to give remuneration. This is as told by the Head of Subdirectorate of BLU Financial Coaching for Education (Ministry of Finance) below: 
"In BLU, its implementation is far better in terms of its performance assessment. Why? This is because in BLU the performance measurement is clear. Internally speaking, there is a performance contract between leaders and their subordinates plus since mid 2014 based on BLU Coaching MoU between the then Minister of Finance and Minister of Education and Culture there is a derivative of that MoU. UX since 2014 has regularly sent its performance contract, from 2014 to 2016. It is used as one of the references in providing remuneration. Particularly, to measure BLU leaders' remuneration."

The rector signs the performance contract based on Key Performance Indicator (KPI) together with the Director General of Treasury. Furthermore, the rector prepares and signs the Sasaran Kerja Pegawai (SKP) or Emplooyees Work Target in order to perform the tasks and functions as well as realizing the performance contract. To achieve the performance set forth in this performance contract, many parties also sign SKP to realize the performance contract. UX's remuneration is a single salary using UX's PNBP fund as its source for the tasks and functions embedded to the field of work and office of Management Officials, Supervisory Board and Secretary of Supervisory Board, as well as UX Employees based on the achievement of predetermined performance targets.

When all regulations related to UX's remuneration have been established, the next step is preparing a remuneration system, beginning from such processes as job analysis, job evaluation, structure formation and grading scale up to determination of remuneration amount. To support the job analysis at University X, a Job Analysis Team is formed. The formation of this Job Analysis Team is established under the Decision of Rector of University X Number 22/UN27/KP/2012 dated 3 January 2012. Meanwhile, the steps in job analysis involve collecting data, preparing job description, determining job requirement, preparing job map and verifying the result of this job analysis.

During the data collection stage, the data on jobs are collected for analysis. Next, the jobs are described in job description forms wherein information on job identity, job position within the organizational structure, main tasks and functions of the jobs, task details (main and additional tasks), work relationship (internal and external), job responsibility as well as information on work environment is elaborated. Based on the job description, job map is made by evaluating the jobs. This job evaluation is a part of human resources management process used to weigh a job to generate job value and job class. The value and class of a job are used to determine the fair and feasible salary in line with the work load and responsibility of the jobs.

UX evaluates the jobs for educators and education staff through self-assesment method using 16 weighting factors in reference to the Regulation of Minister of PAN and RB No 34 Year 2011 (Evaluation Guideline) and Regulation of Head of BKN No 21 Year 2011 (Guideline for Job Evaluation). Job map depicts the entire existing jobs and their position within the work unit and the number of human resources owned at an organization unit. This is done when the job structure and class are known. Finally, the job rank table at UX is as follows:

Table 7. Job Rank

\begin{tabular}{cccc}
\hline NO & JOB NAME & GRADE & TOTAL SCORE RANGE \\
\hline $\mathbf{1}$ & Job Class 17 & 17 & $7180-5601$ \\
$\mathbf{2}$ & Job Class 16 & 16 & $5600-4901$ \\
$\mathbf{3}$ & Job Class 15 & 15 & $4900-3901$ \\
$\mathbf{4}$ & Job Class 14 & 14 & $3900-2801$ \\
$\mathbf{5}$ & Job Class 13 & 13 & $2800-2351$ \\
$\mathbf{6}$ & Job Class 12 & 12 & $2350-1801$ \\
$\mathbf{7}$ & Job Class 11 & 11 & $1800-1451$ \\
$\mathbf{8}$ & Job Class 10 & 10 & $1450-1351$ \\
$\mathbf{9}$ & Job Class 9 & 9 & $1350-1251$ \\
$\mathbf{1 0}$ & Job Class 8 & 8 & $1250-1101$ \\
$\mathbf{1 1}$ & Job Class 7 & 7 & $1100-951$ \\
$\mathbf{1 2}$ & Job Class 6 & 6 & $950-851$ \\
\hline
\end{tabular}




\begin{tabular}{lllc}
\hline $\mathbf{1 3}$ & Job Class 5 & 5 & $850-741$ \\
$\mathbf{1 4}$ & Job Class 4 & 4 & $740-671$ \\
$\mathbf{1 5}$ & Job Class 3 & 3 & $670-651$ \\
$\mathbf{1 6}$ & Job Class 2 & 2 & $650-251$ \\
$\mathbf{1 7}$ & Job Class 1 & 1 & $250-1$ \\
\hline
\end{tabular}

The performance is assessed by comparing the target to the predetermined realization. The remuneration fee which comes from PNBP fund is determined at $30 \%$, and performance incentive is determined at $70 \%$. The performance incentive is given based on the achievement of performance indicators for Educators, in accordance with Law on Teachers and Lecturers No. 14 Year 2005 Article 72. The amount of remuneration is based on the performance achievement indicators for Educators is determined as follows.

Table 8. Performance Achievement Indicator for Educators

\begin{tabular}{lcccc}
\hline Performance & $\begin{array}{c}\text { Individual } \\
\text { Performance } \\
\text { Indicator }\end{array}$ & $\begin{array}{c}\text { Conversion in } \\
\text { Credit } \\
\text { for Educators }\end{array}$ & Amount of Remuneration \\
\hline Incentive \\
Performance
\end{tabular}

In case the credits achieved by employees reaches 6 credits, then the relevant employees shall receive the salary which comes from PNBP at 30\%. If these Educators for three months in a row are nonperforming, then the PNBP salary at 30\% shall not be given. In case the credit achieved by Educators exceeds 17 credits up to 24 credit, then the performance remuneration incentive shall be paid at the same amount as for extraordinary performance indicator. Extraordinary performance is given to Educators with ability to achieve extra performance, support the achievement of UX's Key Performance Indicator and Priority Performance Indicator.

For Educators, the performance achievement is based on 2 components which include job implementation (SKP, additional work, and creativity) with scoring weight of $60 \%$ and work behavior (such aspects as service orientation, integrity, commitment, discipline, cooperation, and leadership) with a scoring weight of $40 \%$.

The remuneration is given based on education system service, with several assumption in reference to the applicable regulations as follows: (1) Each Educator has a mandatory load (obligatory full teaching equivalence EWMP) of 12-16 credits which is performed in 5 business days (Monday to Friday) and (2) For Educators: 7.5 hours x 22 days $=165$ hours $/$ month.

The provisions of remuneration provision is governed under the Regulation of Rector as follows:

1. Determinant Indicators for Remuneration Amount

Remuneration Value $=$ Job Value $\mathrm{x}$ PNBP rupiah index

a. Incentive Performance $=$ Pay for Performance PNBP

b. "Poor" Performance $=25 \% \times(70 \%$ PNBP $)$

c. "Good" Performance $=100 \%$ x (70\% PNBP)

d. "Excellent" Performance $=150 \%$ x $(70 \%$ PNBP $)$

e. "Extraordinary" Performance $=200 \%$ x $(70 \%$ PNBP $)$

2. Determination of Grading for Educators with Additional Duties and Educators 
The performance achievement for Educators with Additional Duties dan Educators is submitted using LS (direct) mechanism. For performance achievement indicator of Educators, each individual should at least do such activities as Teaching, Research, Final Project Guidance, Final Project Examiner, Guidance for student's Community Service, Job Training Guidance, and Academic Guidance as the basis for determining remuneration for performance achievement of each semester.

The calculation of the extent of performance achievement for Educators is based on number of credits (at a minimum 12 credits and at a maximum 24 credits), therefore each of these activities should be equated or assessed in credit unit in the form of equivalency of activities assessed in credit unit.

Table 9. Activity Index in Credit Number

\begin{tabular}{lll}
\hline \multicolumn{1}{c}{ Activity Item } & \multicolumn{1}{c}{ Equivalent to 1 credit } & \multicolumn{1}{c}{ Note } \\
\hline Extra Teaching Hours & 50 minutes & Based on Rektor Decision \\
$\begin{array}{l}\text { Advis or for Final } \\
\text { Project/Thesis/ Dissertation }\end{array}$ & Guidance of final projects of S1, S2 and S3 \\
s. S1/Diploma & 6 Students (as per Rector/WR 1 Decision) \\
b. S2 & 3 Students & \\
c. S3 & 2 Students & \\
& & \\
Final Project Examiner & 4 Students & Proposal Examiner, Final Project \\
& & Examiner, PKL Examiner, Job Training \\
& & Examiner, Comprehensive Test Examiner \\
Advisor of Students Job Training & 25 Students/ 1 Group & KKS Advisor, KKL Advisor, Job \\
& & Training Advisor \\
Academic Advisor & 12 Students & Academic Advisor \\
\hline
\end{tabular}

After assessing and equivalencing all activities into credit, the next step is determining the extent of performance achievement of an Educator (lecturer) for 1 semester based on the following assesment intervals:

Table 10. Performance Achievement Interval

\begin{tabular}{ccc}
\hline No. & Interval of Credits & Performance Achievement \\
\hline $\mathbf{1}$ & $17-24$ & $200 \%$ \\
$\mathbf{2}$ & $13-16$ & $150 \%$ \\
$\mathbf{3}$ & $10-12$ & $100 \%$ \\
$\mathbf{4}$ & $7-9$ & $25 \%$ \\
$\mathbf{5}$ & $0-6$ & $0 \%$ \\
\hline
\end{tabular}

2. Determining Educator Grading

The calculation of the amount of Performance Achievement Remuneration uses formula as Performance Achievement Remuneration Percentage multiplied by Performance Achievement Percentage multiplied by Total Amount of Remuneration.

The remuneration policy for Non-Civil Servant employees will be implemented by considering UX's financial ability, reasonability and proportionality in the jobs with Non-Civil Servant Employee status. UX also applies the 13th remuneration, i.e. a remuneration to be given for the 13th month, which will refer to the government policy in providing the 13th salary as a part of PNS income as mandated by the policy of law in general. In addition to PNS, the 13th remuneration will also be given to non-civil servant employees.

Meanwhile, the policy of remuneration amount to be given for the 13th Remuneration refers to the grading which has been set with a maximum percentage of $100 \%$ will be adjusted with BLU's PNBP prognosis ability and other policies at UX in the current year. 
In accordance with Law No. 3 Year 1992 on Social Security for Workers, Government Regulation No. 14 Year 1993 on Administration of Social Security for Workers Program and Ministerial Regulation of Manpower and Transmigration No. PER-12/MEN/VI/2007 on Technical Guidance for Participation Registration, Premium Payment, Compensation Payment, and Social Security for Workers Service, then the company/institution must provide severance pay and rewards for their contribution to the company/institution based on their years of service. Therefore, the Rector shall give pension savings/pension insurance for non-civil servant employees. This pension savings/pension insurance/severance pay insurance can also be used as pension plan/pension for non-civil servant employees like insurance program for civil servants. This pension saving can be given to employees who have give a full contribution to UX up to their productive age limit/until they are in pension age.

\section{Internalization}

When this remuneration policy was first introduced, some employees rejected it. This was because they lacked information on remuneration. Such a circumstance is explained by the Deputy Dean II FIP below:

"Some protested when this remuneration was introduced for the first time, then we organized some dissemination on that regard. Those protesting it usually did not know what their job classes are or how the assessment would be. However, after some explanation, well they eventually abode by it."

In addition to the protest due to lack of understanding at the initial implementation of remuneration, even until now UX still performs the mechanism of honorarium beyond the remuneration amount. This happens as well in the postgraduate unit. It is due to the lack of experts in specific disciplines. At the postgraduate unit, the fee for guidance and examination of final projects (S2 and S3) is paid beyond the remuneration mechanism. This is as suggested by the Deputy Dean FPPSi below:

"Initially, thesis and dissertation guidances were included in the remuneration scheme, yet many professors objected it. Eventually, we made a compromise to make thesis and dissertation guidances specifically paid from honorarium. It is justified since final project guidance requires specific expertise and the number of advisors is also limited, thus specifically for these activities, we still use honorarium for their payment."

Deputy Rector II suggests a different reason for this. He says the honorarium at postgraduate unit is due to the transitional period that UX is having to shift from honorarium mechanism to remuneration one, hence to minimize the trouble it may cause, the shift towards remuneration mechanism will be performed gradually. Deputy Rector II says as follows:

"The point is that this is a transition, to prevent everyone from being shocked, if they are not included in the remuneration, they are paid separately from sources other than remuneration. This transition is intended to avoid any turmoil among lecturers. Remuneration has its limit, how much something will be paid, how much an extra will be paid and no more payment for something more than that. Most exceed the upper limit, hence lecturers wish to maintain it. Steadily we will change it."

The researcher has informants from 2 faculties whose number of students is substantially different. This is intended to see what differences are made by this different number of students. The first opinion is stated by Deputy Dean II FIP below:

"The rate determined in the remuneration has actually been good enough. We have many students, yet we have a large number of lecturers as well, thus thanks to this remuneration the distribution of welfare becomes more evenly spread. When we still used the honorarium mechanism, only a few people had the control. Nowadays, since the assessment is well- 
defined, more people are grateful for this remuneration. This means they have their welfare improved."

Similar opinion is suggested by the Deputy Dean FPPSi below:

"FPPSi is a faculty, and we know nothing about honorarium mechanism, thus as remuneration is applied, our employees clearly happy for they will have additional income. Moreover, we only have 21 lecturers here. The currently existing rate has been extremely good for our employees here."

From the interview with these 2 informants, it can be concluded that in practice, it turn out no difference whatsoever in terms of remuneration amount between faculties with less and more students. This is because the increased number of students is also followed by increased number of educators. Thus, the more students they have, the more educators they will have as well.

The implementation of remuneration at UX since early 2015 had led to some changes. One of the changes resulting from remuneration is the special team tasked to assess employee's performance. Another change is the use of performance assessment application. This application help educators organize the works they have done such as education, teaching, research, community service, supports and attendance. Since its implementation, remuneration has changed educators' behavior. These educators are more diligent in teaching and conducting research. This is as suggested by the Deputy Dean II FIP below:

"Since remuneration was introduced, the occuring change is obvious, lecturers are more eager in teaching, the attendance increased as well. This is because every extra teaching hour is counted as remuneration credits."

The Deputy Dean FPPSi also explain more or less similarly as follows:

"Currently, lecturers are more dilligent in conducting research, at least each semester they have to publish a journal. This is beyond the research which has been funded. Thus, it is this research which has not been sponsored which will be compensated in this remuneration. It is good for the university, considering research is also one factor considered to measure accreditation. For community service, well there has none so far, since the community service which can be compensated in remuneration is the one conducted at laboratory schools."

The interview is also supported with data from employment regarding the number of research which has increased since the introduction of remuneration at UX. The research conducted by educators increases significantly in semester 2 of 2016, i.e. 597 studies while in semester 2 of 2015 there were only 59 studies. This implies that remuneration improves educators' performance in research.

The change occuring since the introduction of remuneration for educators is improved attendence. This is as suggested by the Head of Employment Division below:

"The change in education staff since the introduction of remuneration is that they are more dilligent in terms of attendance (finger print). We know this because we check their attendance recap, from which we can see how dilligent they are in terms of attendance. However, we have not seen another change since the performance measurement is varied from one educator to another."

The Expert Staff of WR II also states similar phenomenon as follows:

"Lecturers change significantly since they have a well-defined performance measurement. They teach more dilligently, so is in terms of research. Meanwhile for education staff, no significant change is seen yet, they remain the same as before the remuneration was introduced. The performance measurement for education staff will be evaluated later. We still do not know which room needs improvement, but we will see it later." 
The education staff performance measurement still needs re-evaluation. This is because the expected change from remuneration ideal has not been materialized yet. The aid such as application for educators is also expected to help measure the performance of education staff.

\section{CONCLUSION}

Based on the model developed by Dambrin et al. (2007), four main conclusions can be drawn from this research. Firstly, external pressure in the form of regulation which should be accepted by UX is the most common form of coercive isomorphism (Harcourt et al., 2005). Secondly, benchmarking with three universities with nearly similar characteristics in preparing the consideration of remuneration aspects is a form of mimetic isomorphism. Thirdly, the technical guideline prepared by UX by using and modifying performance allowance regulation is a form of mimetic isomorphism. Fourthly, at the beginning of remuneration introduction, turmoil occurs among employees due to lack of information on its calculation and job class of each employee. Additionally, there is a specific condition applied in the postgraduate unit in relation to such activities as guiding and examining students' final projects which are separated from the remuneration mechanism. It is expected that this research can give an input for refining the policies in relation to pressure and change of behavior towards the introduction of remuneration at UX. Also, it is expected that this research would motivate other BLU Work Units in improving their remuneration implementation. Its limitation is its time which makes its exploration on remuneration is limited to a few informants. In addition, it also has the participation limitation since the researcher is not directly involved in the process of preparing and implementing remuneration, which possibly prevent the researcher from holistically understand the remuneration institutionalization process at UX. In order to understand remuneration from different perspective, it is recommended to use another analysis tool such as to see the behavior of those parties playing certain roles in remuneration since remuneration is actually related to individual welfare which results in the change in their behavior.

\section{REFERENCES}

Alawiya, N. Yuliantiningsih, A. Sudrajat, T. dan Sari, D. P. Y. P. (2013). Kebijakan Remunerasi Pegawai Negeri Sipil. Jurnal Dinamika Hukum Vol. 13, No. 2, Mei 2013.

Basuki, H. 2006. Penelitian Kualitatif untuk Ilmu-Ilmu Kemanusiaan dan Budaya. Jakarta

Blaskova, M. And Blasko, R. (2014). Motivating University Teachers Through Prism of Their Remuneration. Procedia Sosial and Behavioral Sciences 110 (2014) 595-606.

Burrel, G. and Morgan, G. 1979. Sociological Paradigms and Organizational Analysis: Elements of the Sociology of Corporate Life. Aldershot. Ashgate. Publishing Limited. England

Covaleski, M.A., Dirsmith, M.W. and Michelman, J.E. (1993), An institutional theory perspective on the DRG framework case-mix accounting systems and health-care organizations. Accounting, Organizations and Society, Vol. 18, pp. 65-80.

Creswell, J.W. (2015). Penelitian Kualitatif \& Desain Riset: Memilih Di Antara Lima Pendekatan. Pustaka Pelajar. Yogyakarta.

Dambrin, C., Lambert, C. and Sponem, S. (2007). Control and change - analysis of the process and institutionalization. Management Accounting Research, Vol. 18, pp. 172-208.

Dessler, G. (1997). Manajemen SUMber Daya Manusia. Jakarta: PT. Prenhalindo 
Dillard, J.F., Rigsby, J.T. and Goodman, C. (2004). The making and remaking of organization context: duality and the institutionalization process. Accounting, Auditing \& Accountability Journal, Vol. 17 No. 4, pp. 506-42.

DiMaggio, P.J \& W. Powell. (1983). The iron cage revisited: institutional isomorphism and collective rationality in organizational fields. American Sociological Review, 48 (1983), 147-60.

DiMaggio, P.J \& W. Powell. 1991. Introduction, The New Institutionalism in Organizational Analysis, University of Chicago Press.

Gustika, R. (2013). Pengaruh Pemberian Remunerasi Terhadap Kinerja Anggota Polri Polres Pasaman. EJurnal Apresiasi Ekonomi VolUMe 1, Nomor 1, Januari 2013.

Hariadi, B. (2013). Revitalisasi Pabrik Gula Rajawali Mengungkap Dinamika Proses Institusionalisasi. Disertasi Tidak Dipublikasikan. Universitas Brawijaya, Malang.

Harcourt, M., Lam, H., \& Harcourt, S. (2005). Discriminatory Practices in Hiring: Institusional and Rational Economic Perspectives. The International Journal of HUMan Resource Management. Vol.16(11). pp. 2113-2132.

Harun, H. Van Peursem, K \& Eggleton, I. (2012). Institutionalization of accrual accounting in the Indonesian publik sector. Journal of Accounting \& Organizational Change. Vol. 8 Iss 3 pp. 257 285.

Hood, C. (1991). A Publik Management for All Seasons? Publik Administration, 69, 3-19. http://doi.org/10.1111/j.1467-9299.1991.tb00779.x

Hopper, T. \& Major, M. (2007). Extending institutional analysis through theoretical triangulation: regulation and activity-based costing in Portuguese telecommunications. European Accounting Review, Vol. 16 No. 1, pp. 59-97.

Jones, G.R. 2001. Organizational Theory Text and Cases. Prentice Hall International Inc. New Jersey

Kamayanti, A. 2016. Metodologi Penelitian Kualitatif Akuntansi. Yayasan RUMah Peneleh. Jakarta

Kawedar, W. (2015). Pengaruh Penganggaran Partisipatif, Remunerasi, Dan Karakteristik Demografi Terhadap Kinerja Manajerial Dengan Berbagi Pengetahuan Sebagai Variabel Mediasi. Disertasi Tidak Dipublikasikan. Universitas Brawijaya, Malang

Kementerian Kesehatan. Peraturan Menteri Kesehatan Nomor 68 Tahun 2014 tentang Pedoman Penyusunan Sistem Remunerasi Pegawai Politeknik Kesehatan di Lingkungan Kementerian Kesehatan yang Menerapkan Pola Pengelolaan Badan Layanan Umum. 2014. Jakarta

Kementerian Keuangan. Peraturan Menteri Keuangan Nomor 10 Tahun 2006 tentang Pedoman Penetapan Remunerasi Bagi Pejabat Pengelola, Dewan Pengawas dan Pegawai Badan Layanan Umum. 2006.. Jakarta

Kementerian Keuangan. Keputusan Menteri Keuangan Nomor 279/KMK.05/2008 tentang Penetapan Universitas Negeri Malang pada Departemen Pendidikan Nasional sebagai Instansi Pemerintah yang Menerapkan Pengelolaan Keuangan Badan Layanan Umum. 2008. Jakarta

Kementerian Keuangan. Keputusan Menteri Keuangan Nomor 390/KMK.05/2015 tentang Penetapan Remunerasi bagi Pejabat Pengelola, Dewan Pengawas, dan Pegawai Badan Layanan Umum Universitas Negeri Malang. 2015. Jakarta

Kementerian Riset, Teknologi, dan Pendidikan Tinggi. Peraturan Menteri Riset, Teknologi, dan Pendidikan Tinggi Nomor 31 tahun 2016 tentang Pemberian Tunjangan Kinerja Pegawai di Lingkungan Kementerian Riset, Teknologi, dan Pendidikan Tinggi. 2016. Jakarta 
Lukman, M. (2013). Badan Layanan Umum; Dari Birokrasi Menuju Korporasi. Jakarta: Bumi Aksara Publisher

Mahmudi. 2003. New Publik Management (NPM): Pendekatan Baru Manajemen Sektor Publik. SINERGI Kajian Bisnis Dan Manajemen 6 (1): 69-76.

Nurdiwaty, D. (2014). Institusionalisasi Akuntansi Sosial Pada Perum Perhutani Blitar. Tesis Tidak Dipublikasikan. Universitas Brawijaya, Malang.

Pemerintah RI Undang-Undang Nomor 1 Tahun 2004 tentang Perbendaharaan Negara. 2004. Jakarta

Presiden RI. Peraturan Pemerintah Nomor 23 Tahun 2005 tentang Pengelolaan Keuangan Badan Layanan Umum. 2005. Jakarta

Presiden RI. Peraturan Presiden Nomor 81 Tahun 2010 tentang Grand Design Reformasi Birokrasi 20102025. 2010. Jakarta

Presiden RI. Peraturan Presiden Nomor 88 Tahun 2013 tentang Tunjangan Kinerja Pegawai di Lingkungan Kementerian Pendidikan dan Kebudayaan. 2013. Jakarta

Presiden RI. Peraturan Presiden Nomor 32 Tahun 2016 tentang Tunjangan Kinerja Pegawai di Lingkungan Kementerian Riset, Teknologi, dan Pendidikan Tinggi. 2016. Jakarta

Rusli, HB. (2013). Kebijakan Remunerasi Berbasis Kinerja. http://pustaka.unpad.ac.id/ diakses pada 20 juni 2015.

Rusman. (2015). Pengaruh Remunerasi, Budaya Organisasi, Karakteristik Demografi, Dan Pengawasan Fungsional Terhadap Kinerja Pegawai Pengelola Keuangan. Tesis Tidak Dipublikasikan. Universitas Brawijaya, Malang.

Salim, A. (2001). Teori dan Paradigma Penelitian Sosial (Pemikiran Norman K. Denzin dan Egon Guba, dan penerapannya). PT. Tiara Wacana. Yogyakarta.

Sukoharsono, E.G. 2006. Alternatif Riset Kualitatif Sains Akuntansi: Biografi, Phenomenologi, Grounded Theory, Critical Etnografi dan Case Study. Bahan Pelatihan Metodologi Penelitian Pendekatan Multiparadigma: Breakthrough untuk Transformasi Akuntansi. Fakultas Ekonomi. Universitas Brawijaya. Malang.

Universitas Negeri Malang. Peraturan Rektor Universitas Negeri Malang Nomor 7 Tahun 2015 tentang Pedoman Pelaksanaan Remunerasi bagi Dosen dan Tenaga Kependidikan di Universitas Negeri Malang. 2015. Malang

Yin R. K. (2002). Studi Kasus Desain dan Metode. Penerjemah M. Djauzi Mudzakir-Ed.1-11. Rajawali Pers. Jakarta. 